ning of microbial groups in conditions of anthropogenic loading]. Kyiv: Oberehy [in Ukrainian].

9. Titova, V.I. \& Kozlov, A.V. (2012). Metody otcenki funktcionirovaniia mikrobotcenoza pochvy, uchastvuiushchego v transformatcii organicheskogo vesh- chestva: nauchno- metodicheskoe posobie [Methods of evaluation of the functioning of the microbocenosis of soil involved in the transformation of organic matter: scientific methodical manual]. N. Novgorod: Nizhegorodskaia s.-kh. akademiia [in Russian].

\title{
INFLUENCE OF MISCANTHUS GIGANTEUS CULTIVATION ON THE ORIBATID AND COLEMBOL QUANTITIES IN URBANOZEM OF KHARKIV REGION
}

\begin{abstract}
A. Kholodna
ННЦ «Інститут грунтознавства та агрохімії імені О.Н. Соколовського»

Встановлено значне підвищення активності грунтових мікроартропод, а саме - орибатид і колембол за вирощування міскантусу гігантського (Miscanthus x giganteus) на різних типах урбаноземів. Обгрунтовано перспективність вирощування цієї культури на маргінальних антропогенно-деградованих грунтах міських масивів з їх одночасною рекультивацією та введенням у господарський обіг, зокрема для потреб біоенергетичної галузі країни.
\end{abstract}

Ключові слова: міскантус гігантський, маргінальні землі, урбаноземи, мікроартроподи, біологічна рекультивація, фітомеліоранти.

Natural soil cover is greatly accelerated not only due to evolutionary processes, but also through the constant growth of the pace of anthropogenic activity. Intact natural soils in our time have survived exclusively in preserves, national parks, on unprotected river slopes, on non-meliorated river floodplains and under indigenous forests.

In this aspect, the rational and balanced use of not only traditional «agro-lands», but also the reclamation of «urban» lands with the purpose of attracting them for cultivating crops, becomes important. Under the term «urban soils», we mean anthropogenically altered, and therefore marginal [1], soils of urban areas, whose artificial profile has a surface layer of thickness up to $50 \mathrm{~cm}$, created by man by pouring, mixing, burial of materials (substrates) of purely urban origin [2,3]. Because of this, the functions and properties of such soils are subject of considerable disturbance, especially in terms of the functioning of their biological component.

(C) A. Kholodna, 2018
One of the most effective ways of monitoring the biological properties of soils, which is necessary for the development of management measures [4] to improve their soil and ecological status, is the study of the change in the number of microfauna, namely microarthropods - soil invertebrates, which, in favorable conditions, act as natural faunal reclamators. After all, changes in the soil as a result of human activity at the initial stage, which sometimes can't be detected by physical and chemical methods, can be determined with high accuracy on the basis of the species and ecological composition of soil invertebrates.

In our studies we focused on two groups of microarthropods. Oribatida (Oribatida, Acarina) - shell mites, is one of the most numerous and dominant groups of soil arthropods. High numbers, a large variety of species and life forms, as well as food specialization, determine the significant contribution of cartilage mites in the processes of biotransformation of organic matter.

Collembola or Pomoros are among the ancient land-based arthropods. Collembola are adapted to various soil regimes and form 
faunal complexes that are characteristic of a certain type of soil. Because of physiological vulnerability, collembola react sensitively even to minor changes in environmental parameters. Therefore, their presence and quantity are important indicators of soils «health».

In our view the foregoing can serve as the basis for expanding research on the study and improvement of biological and ecological functions of anthropogenically degraded soils, which, to varying degrees, are available in every locality, and therefore they can rightly be considered as an ecological and biological screen of human influence on the natural environment.

Therefore, study of changes in the number of representatives of the microarthropods group and search for ways to improve their conditions on urban soils will determine their role as biological soil recultivators. On the example of anthropogenically degraded soils in Kharkiv region as phytoameliorants, we propose cultivation of energy crops, in particular the giant miscanthus, which occupies a leading position in the line of bioenergy production.

The purpose of our research was to determine the effect of cultivating giant miscanthus on the number of oribatida and collembola in urban areas of Kharkiv region. It is very important to mention that before planting this energy crop there've been no other vegetation on these soils.

\section{MATERIALS AND METHODS OF RESEARCH}

Small-field stationary experiments of giant miscanthus cultivation were laid in spring of 2017 on the territory of the dendrological park of Kharkiv National Agrarian University named after V.V. Dokuchaev on three marginal urban soils, namely: urban chornozem, urban lithosoil and urban meadow chornozem.

The urban chornozem profile is a completely homogenized soil mass, formed as a result of human activity on the site of typical chornozem.

Urban lithosoil is essentially a matter of maternal breed (loess loam) of the PrylukyYiddish Terrace.

Urban meadow chornozem was formed during anthropogenic activity, namely, arti- ficial displacement of the upper part of the humus profile from the above-ground soil.

From each soil in three replicates an average soil sample was taken to determine the amount of microarthropods in the soil, which was carried out in accordance with generally accepted methods of soil and zoological research $[5,6]$.

\section{RESULTS AND DISCUSSION}

It was determined that at the end of the vegetative period the average height of plants of miscanthus on urban chornozem was the highest among others $-114.6 \mathrm{~cm}$; on urban lithosoil $-100.2 \mathrm{~cm} ; 76.7 \mathrm{~cm}$ on urban meadow chornozem. It is quite clear that the largest vegetative mass was obtained on urban chornozem because of the fact that this soil was formed due to anthropogenic degradation of one of the most fertile soils typical chornozem. Therefore, this soil has retained the properties of its «ancestor» to a certain extent, namely, a significant content of nutrients, organic carbon content, structure, porosity, and others.

In our opinion, rather active growth of giant miscanthus on urban lithosoil is due to the high content of macro- and trace elements in the loam, from which urban lithosoils are formed. The latter, due to the improvement of nutrition, causes intensive development of the root system and aboveground part of miscanthus plants which in turn promotes the activation of vital activity of microarthropods. The loams are characterized by welldetected porosity resulting from the activity of plants, due to which there is considerable space for the activity of invertebrates.

Urban meadow chornozem was formed by displacement of significant soil layers during the construction of the campus. Because of this, the structure of the primary meadow chornozem soil has been catastrophically disturbed. The air-water regime of this urban soil is the worst of the represented ones. All this has become the cause of the passive growth of miscanthus plants.

It was determined that in summer the population of oribatida in urban soils under the plants of miscanthus, compared with the con- 
trol, increased: in urban chornozem from 103 to $160 \mathrm{sp} . / \mathrm{m}^{2}$; in urban lithosoil from 80 to $187 \mathrm{sp} . / \mathrm{m}^{2}$ and in urban meadow chornozem from 213 to $2053 \mathrm{sp} . / \mathrm{m}^{2}$. In the rows of miscanthus, the number of armpits also increased in accordance with the control (Table 1).

Thus, on the explored urban areas direct dynamics of increase in the number of oribatida in summer was determined both under the plants of miscanthus and in the row spacing. In our opinion, the resulted pattern shows that plants form a favorable ecological niche for increasing the microfauna's activity, due to the branching of the roots (rhizomes), root extracts and the creation of a special microclimate.

At the end of the vegetation season of 2017 growth in the population of oribatida was proved on urban soils in all variants of the held research.

The dynamics of collembola in summer was similar to the dynamics of the number of oribatida (table 2). In the urban chornozem the number of collembola was the highest on the control version, and the smallest in the rows.

In other urban soils maximum was traced on a variant under plants, and minimum on the control. At the same time, on the urban meadow chornozem under the plants of the giant miscanthus was the largest collembola amount among all the variants of the experiment $-720 \mathrm{sp} . / \mathrm{m}^{2}$.

In autumn of 2017, the number of collembola increased for all variants without exception.

The most significant changes were traced on urban lithosoil in the under plants variant - an increase in collembola population from 533 to $3840 \mathrm{sp} . / \mathrm{m}^{2}$, that is 7.2 times bigger. Similarly, on the urban meadow chornozem there was a significant increase in collembola number under plants and in row spacing -2907 and $2933 \mathrm{sp} . / \mathrm{m}^{2}$ in autumn according to 320 and $133 \mathrm{sp} . / \mathrm{m}^{2}$ in summer.

Under such conditions, soil invertebrates use this ecological niche for their own needs, so they accelerate the pro-
Table 1

The number of oribatida during the vegetation period of giant miscanthus

\begin{tabular}{l|c|c}
\hline \multirow{2}{*}{ Variant } & \multicolumn{2}{c}{ The number of oribatida, sp. $/ \mathrm{m}^{2}$} \\
\cline { 2 - 3 } & Summer 2017 & Autumn 2017 \\
\hline \hline Urban chornozem \\
\hline Control & 103 & 240 \\
\hline $\begin{array}{l}\text { Giant } \\
\text { miscanthus }\end{array}$ & 160 & 773 \\
\hline Rows & 133 & 400 \\
\hline Urban lithosoil & & \\
\hline Control & 187 & 960 \\
\hline $\begin{array}{l}\text { Giant } \\
\text { miscanthus }\end{array}$ & 107 & 693 \\
\hline Rows & 187 & 213 \\
\hline \multicolumn{3}{|c}{ Urban meadow chornozem } \\
\hline Control & 720 & 2053 \\
\hline $\begin{array}{l}\text { Giant } \\
\text { miscanthus }\end{array}$ & 267 & 800 \\
\hline Rows & & \\
\hline
\end{tabular}

Table 2

\section{The number of collembola during the vegetation period of giant miscanthus}

\begin{tabular}{l|c|c}
\hline \multirow{2}{*}{ Variant } & \multicolumn{2}{|c}{ The number of collembola, sp. $/ \mathrm{m}^{2}$} \\
\cline { 2 - 3 } & Summer 2017 & Autumn 2017 \\
\hline \hline Crban chornozem \\
\hline Control & 187 & 240 \\
\hline Giant miscanthus & 133 & 707 \\
\hline Rows & 53 & 320 \\
\hline Urban lithosoil & & 347 \\
\hline Control & 107 & 3840 \\
\hline Giant miscanthus & 533 & 1013 \\
\hline Rows & 213 & 1307 \\
\hline \multicolumn{3}{|c}{ Urban meadow chornozem } \\
\hline Control & 907 & 2907 \\
\hline Giant miscanthus & 320 & 2933 \\
\hline Rows & 133 & \\
\hline
\end{tabular}


cesses of their reproduction. As a result, their populations in the upper layer of soil increase, namely in the layer up to $40 \mathrm{~cm}$ - the depth of the miscanthus' rhizomes web.

It should be noted that microfauna has always been and is one of the decisive factors in the accumulation of organic matter in the soils. Therefore, the activation of the microfauna's activity in the urban areas cultivated with giant miscanthus indicates the prospect of this direction of biological reclamation, especially in the aspect of resource conservation and economic feasibility. From the point of view of the fact that urban areas are often at risk (for example, because of the threat of re-excavation over heating paths), it is possible to temporarily use them as plots of propagation of energy crops not only for bioenergy purposes, but also as biorecultivation of anthropogenically degraded territories.
In general, it can be noted that cultivation of giant miscanthus on anthropogenically degraded soils leads the soil-forming process in a positive direction, positively affects the environmental situation of the environment and greatly improves the overall view of the urbanized territories.

\section{CONCLUSIONS}

The fact that urban chornozem was formed due to anthropogenic influence on the typical chornozem and is the most productive of the studied urban soils caused a more significant increase in the vegetative mass comparing to others urban soils.

The number of soil invertebrates, such as oribatida and collembola, grew during the growth period of giant miscanthus in the urban soils, indicating an improvement in the ecological situation.

\section{ЛIТЕРАТУРА}

1. Tsapko Yu.L. Changes of biological activity of degraded chernozems in Kharkiv region due to giant miscanthus cultivation / Yu.L. Tsapko, A.S. Kholodnaya // Colloquium-journal. - 2017. - No. 10. P. 9-12.

2. Тихоненко Д.Г. Проблеми картографування урбаноземів / Д.Г. Тихоненко, М.О. Горін / Вісн. ХНАУ ім. В.В. Докучаєва. - 2013. - № 2. - С. 5-11. - (Серія: Грунтознавство, агрохімія, землеробство, лісове господарство, екологія грунтів).

3. Тихоненко Д.Г. Сучасний стан і перспективи використання ландшафтних особливостей і грунтового покриву території навчально-дослідного господарства «Докучаєвське» / Д.Г. Тихоненко, М.О. Горін // Вісник ХНАУ. - 2006. - № 7. C. 3-19.

4. Marginal Lands: Concept Assessment and Management / S. Kang, W.M. Post, J.A. Nichols et al. // Journal of Agricultural Science. - 2013. Vol. 5, No. 5. - P. 129-139.

5. Гиляров М.С. Методы почвенно-зоологических исследований / М.С. Гиляров. - М.: Наука, 1975. $-280 \mathrm{c}$.

6. Определение колембол фауны СССР / под ред. Н.М. Черновой, Б.Р. Стригановой. - М.: Наука, 1988. - 124 c.

\section{REFERENCES}

1. Tsapko, Yu.L., Kholodnaya, A.S. (2017). Changes of biological activity of degraded chernozems in Kharkiv region due to giant miscanthus cultivation. Colloquium-journal, 10, 9-12 [in English].

2. Tyhonenko, D.G., Gorin, M.O. (2013). Problemy kartografuvannya urbanozemiv [Problems of mapping of urban soils]. Visn. HNAU im. V.V. Dokuchaeva - Bulletin of the KhNAU named after V.V. Dokuchaev, 2, 5-11 [in Ukrainian].

3. Tyhonenko, D.G. \& Gorin, M.O. (2006). Suchasnyi stan i perspektyvy vykorystannya landshaftnyh osoblyvostei i gruntovogo pokryvu terytorii navchalno-doslidnogo gospodarstva «Dokuchaevske» [Modern condition and perspectives of using landscape's specifics and soil cover of the territory of educationally-exploring farming «Dokuchaevske»]. Visn. HNAU im. V.V. Dokuchaeva - Bulletin of the KhNAU named after V.V. Dokuchaev, 7, 3-19 [in Ukrainian].

4. Kang, S., Post, W.M., Nichols, J.A., Wang1, D., West, T.O., Bandaruamp, V. \& Izaurralde, R.C. (2013). Marginal Lands: Concept, Assessment and Management. Journal of Agricultural Science, 5, 129-139 [in English].

5. Gilyarov, M.S. (1975). Metody pochvenno-zoologicheskih issledovaniy [Methods of soil-zoological research]. Moskva: Nauka [in Russian].

6. Chernova, N.M. \& Striganova, B.R (1988). Opredelenie kolembol fauny SSSR [Definition of collembola in fauna of USSR]. Moskva: Nauka [in Russian]. 